\title{
PENGGUNAAN PATI SAGU MODIFIKASI FOSFAT TERHADAP SIFAT ORGANOLEPTIK SOSIS IKAN PATIN (Pangasius hypophtalmus)
}

\author{
THE USE OF PHOSPHATE MODIFICATION SAGO STARCH ON ORGANOLEPTIC \\ PROPERTIES OF FISH SAUSAGE (Pangasius hypophtalmus)
}

\author{
Teltje Koapaha, Teneke Langi, dan Lana E. Lalujan \\ Jurusan Teknologi Pertanian Fakultas Pertanian Universitas Sam Ratulangi Manado \\ e-mail: Teltjekoapaha@yahoo.com
}

\begin{abstract}
Beef and chicken sausages have been widely popular in all classes of the society, however fish sausage has not being recognized and not available in the market yet. In the production of fish sausage, the ratio between fish flesh and tapioca as well as other igredients such as cooking salt, sugar, skim-milk, ice and flavoring agent played important role on the quality of fish sausages. This study aimed to find out the effect ratio of composite sago starch on the organoleptic quality of fish sausage. The randomized design were used in this experiment. The experiment was repilicated three times and the parameters observed organoleptic were taste, texture, colour, flavor of properties fish sausage.The modification treatment were the using $0.25 \%$ STPP. Result showed that the composite sago starch of $50: 50$ and $10 \%$ of it used in fish sausage production gave the most preferable organoleptic properties with the texture $0.04 \mathrm{~mm} / \mathrm{g} . \mathrm{sec}$, taste, colour, flavor of properties fish sausage.
\end{abstract}

Key words : Starch,Phosphate, Modification, Fish Sausage, Organoleptic

\begin{abstract}
ABSTRAK
Sosis dari daging ayam dan sapi sudah dikenal masyarakat luas, namun sosis dari daging ikan belum dikenal bahkan belum dijual di pasaran. Pada proses pembuatan sosis dari daging ikan , rasio daging ikan dan pati serta bahan tambahan lain seperti gula garam, susu skim, es dan bumbu penyedap berperan penting dalam menentukan kwalitas sosis ikan. Hal ini erat hubungannya dengan pembentukan mtriks gel protein, pati lemak dalam bentuk system emulsi sosis yang baik. Tujuan dari penelitian yaitu mempelajari pengaruh rasio pati sagu komposit terhadap sifat organoleptik. Menggunakan Rancangan Acak Lengkap faktor tunggal yaitu pati sagu modifikasi fosfat konsetrasi 0,25\% STPP dalam pati sagu komposit 50:50 dan Rasio pati sagu komposit terhadap daging ikan 10\%; 20\%; 30\%, diulang 3 kali. Pengamatan organoleptik meliputi :rasa, tekstur, warna, bau sosis ikan. Hasil penelitian perlakuan terbaik diperoleh pada pati sagu komposit yaitu pati sagu alami diambah dengan pati sagu modifikasi 50:50, rasio $10 \%$ terhadap daging ikan dengan hasil uji organoleptik terhadap rasa, tekstur, warna, baus paling disukai panelis, nilai tekstur dengan alat penetrometer yaitu $0,04 \mathrm{~mm} / \mathrm{g}$.det. Kata kunci: Pati Sagu, Fospat, Modifikasi, Sosis ikan Organoleptik
\end{abstract}




\section{PENDAHULUAN}

Sagu metroxylon sagu Roof (sagu leavis rumphius), merupakan salah satu komoditi tanaman pangan sumber karbohidrat yang potensial (Haska, 2004). Menurut Winarni dan Fonthea (2003), potensi sagu yang cukup besar tersebut memerlukan usaha diversifikasi produk untuk dapat memanfaatkan dan meningkatkan daya terima masyarakat yang dikenal sebagai produk "value added". Beberapa jenis produk "value added" yang dapat dikembangkan dalam masyarakat dan sudah dikenal seperti bakso ikan, pindang presto, sosis ikan, nuggets ikan, pangsit ikan dan lain-lain.

Haryanto dan Pangloli (1992), menyatakan bahwa komponen terbesar dalam pati sagu adalah karbohidrat yaitu dalam bentuk pati. Pati sagu mengandung $73 \%$ amilopektin dan $27 \%$ amilosa. Kandungan amilopektin yang tinggi pati sagu tidak memungkinkan digunakan untuk pengolahan produk-produk olahan basah seperti; roti dan cake, karena amilopektin yang tinggi memberikan sifat lengket dan tekstur yang keras pada produk. Liu, Ramsden and Corke (1999), menyatakan bahwa untuk mengatasi hal tersebut dilakukan modifikasi kimia pada pati, guna meningkatkan sifat-sifat spesifik dan memperluas penggunaan dalam produk pangan. Estiati (2006), juga menyatakan bahwa modifikasi kimia seperti pengikatan silang dapat mengubah sifat kohesif (lengket) dan meningkatkan viskositas pati.

Soeparno (1992), menyatakan bahwa sosis ikan adalah hasil olahan daging ikan yang diberi bumbu kemudian dimasukkan dalam wadah berupa selongsong dan dimasak. Produk sosis yang sekarang populer adalah yang berasal dari daging ayam (chicken sausage), tetapi pada kenyataannya sosis daging ayam tersebut diperoleh dengan harga yang mahal dan kebanyakan dikonsumsi oleh kalangan menengah ke atas. Oleh karena itu dipandang perlu dilakukan suatu penelitian tentang penggunaan daging ikan serta usaha penganekaragaman (diversifikasi) dari produkproduk olahan ikan dengan alasan harganya lebih murah, terjangkau oleh masyarakat kalangan menengah ke bawah yaitu membuat sosis ikan (fish sausage) (Taswir, 1992). Hal ini dengan pertimbangan bahwa ikan umumnya bernilai gizi tinggi yaitu sebagai sumber protein (17-20\%), mudah dicerna dan sedikit mengandung kolesterol.

Handayani (1995), menyatakan bahwa pada umumnya ikan berdaging putih mempunyai elastisitas yang lebih baik dari pada ikan berdaging merah. Dalam pengolahan, kemampuan membentuk elastisitas daging ikan dipengaruhi oleh protein miofibrilar. Sedangkan menurut Suzuki (1983), protein miofibrilar meliputi $66-77 \%$ dari total daging ikan mengandung miosin. Miosin memegang peranan penting dalam penggumpalan dan pembentukan gel bila daging ikan diproses. Berdasarkan hal tersebut di atas serta keistimewaan yang dimiliki ikan patin yaitu memiliki warna daging yang putih dan struktur kenyal, maka daging ikan patin baik diolah sebagai bahan baku pada pembuatan sosis ikan.

Hadiwiyoto (1983) dan Moedjiharto (2000), sosis yang bermutu baik adalah produk sosis yang telah memenuhi standar mutu secara kimia dan secara organoleptik sosis harus kompak, kenyal (bertekstur empuk) serta rasa dan aroma yang baik sesuai dengan bahan baku yang digunakan.

Kualitas sosis sebagai produk daging restrukturisasi ditentukan oleh kemampuan saling mengikat antara partikel daging dan bahan-bahan lain yang ditambahkan, terutama jumlah pati yang ditambahkan sebagai bahan pengisi (filler) (Moedjiharto, 2003). Pada penelitian ini menggunakan pati sagu komposit yaitu pati sagu alami ditambah pati sagu modifikasi fosfat $(50: 50)$ dan rasio pati sagu komposit sebagai bahan pengisi (filler) terhadap daging ikan patin untuk mendapatkan sosis ikan dengan sifat organoleptik yang baik.

Penelitian ini bertujuan untuk mendapatkan rasio pati sagu komposit terhadap daging ikan dalam pembuatan sosis yang secara organoleptk diterima oleh konsumen.

\section{METODE PENELITIAN}

Penelitian ini dilaksanakan di Laboratorium Mutu dan Keamanan Pangan Jurusan Teknologi Hasil Pertanian Fakultas Teknologi Pangan Universitas Brawijaya, Laboratorium Sentral IImu 
dan Teknologi Pangan Universitas Brawijaya. Pada bulan Oktober - Desember 2008.

Bahan yang digunakan dalam penelitian adalah pati sagu alami, pati sagu modifikasi fosfat konsentrasi $0,25 \%$ STPP, Ikan patin segar diperoleh dari pedagang Pasar Besar Malang \pm 350-400 g/ekor.

Bahan yang digunakan untuk pembuatan sosis meliputi : daging ikan patin, pati sagu komposit (PSA+PSMF), es, susu skim, minyak goreng bimoli dan bumbu-bumbu sesuai perlakuan. Peralatan yang digunakan pada penelitian ini meliputi: timbangan analitik, ayakan 100 mesh, pH meter, alat pengering kabinet, chopper, penetrometer, desikator.

Penelitian ini menggunakan Rancangan Acak Lengkap (RAL) dengan faktor tunggal yang terdiri dari tiga (3) perlakuan yaitu:

$\mathrm{R} 1=10$ pati sagu komposit $+90 \%$ daging ikan; $\mathrm{R} 2=$ $20 \%$ pati sagu komposit $+80 \%$ daging ikan; R3 = $30 \%$ pati sagu komposit $+70 \%$ daging ikan. Setiap perlakuan diulang 3 kali.

Pati sagu dikeringkan dan diayak terlebih dahulu untuk menghilangkan kotoran dan benda asing yang mungkin terikat pada pati. Pati sagu ditimbang sebanyak 150 gram lalu ditambahkan akuades $\pm 210 \mathrm{ml}$ diaduk sampai rata, kemudian ditambahkan $\mathrm{Na}_{2} \mathrm{SO}_{4} 10 \%$ (15 g), aduk sampai rata dan secara perlahan dilakukan alkalisasi dengan penambahan $\mathrm{NaOH} 1 \mathrm{~N}$ sampai $\mathrm{pH}$ 10. Setelah tercapai $\mathrm{pH}$ tersebut tambahkan sodium tripolyphosphate (STPP) dengan tingkat konsentrasi $0,25 \%$, diaduk dengan stirrer pada suhu kamar (25$\left.26^{\circ} \mathrm{C}\right)$ selama 60 menit. Kemudian tambahkan larutan dengan $\mathrm{HCl} 1 \mathrm{~N}$ sampai $\mathrm{pH} 6,5$. Selanjutnya dilakukan pencucian sebanyak 2 kali $120 \mathrm{ml}$ akuades dan diendapkan pada suhu ruang selama 24 jam. Keringkan dengan alat pengering kabinet suhu $50^{\circ} \mathrm{C}$ selama \pm 6 jam. Dinginkan pada suhu ruang, grinder dan ayak dengan ayakan 100 mesh.

Ikan patin disiangi, dibuang isi perut, kepala, kulit, tulang, duri dan sirip. Ambil dagingnya kemudian dicuci. Daging ikan (fillet) sesuai perlakuan ditambahkan es $15 \mathrm{~g}$ dan dihaluskan dengan chopper selama \pm 1-2 menit. Daging halus ditambahkan susu skim $7 \mathrm{~g}$, pati sagu komposit ( $50 \%$ pati sagu alami $+50 \%$ pati sagu modifikasi fospat), minyak goreng bimoli $5 \mathrm{~g}$, garam $2 \mathrm{~g}$, lada $0,3 \mathrm{~g}$, pala, $0,1 \mathrm{~g}$, bawang putih $1 \mathrm{~g}$, bawang merah $1 \mathrm{~g}$, gula pasir $0,5 \mathrm{~g}$. Adonan dicampur merata (homogen). Selanjutnya dilakukan pengisian kedalam selongsong sosis (cassing). Ukuran panjang sosis $\pm 5 \mathrm{~cm}$. Sosis mentah yang diperoleh dikukus pada suhu $90-95^{\circ} \mathrm{C}$ selama 30 menit. Angkat dan didinginkan.

Parameter yang diamati pada sosis ikan meliputi uji fisik yaitu tekstur (penetrometer) (Susanto dan Yuwono, 2001), uji organoleptik yaitu tingkat kesukaan meliputi; rasa, warna, bau, tekstur (Rahayu, 2001).

\section{Analisis Data}

Data hasil uji organoleptik dianalisis dengan statistik non parametrik menggunakan uji Friedman (Steel and Torrie, 1994 dan Yitnosumarno, 1990). Sedangkan untuk menentukan perlakuan terbaik dengan metode indeks efektifitas (Susrini, 2005).

\section{HASIL DAN PEMBAHASAN}

Hasil analisis ragam tekstur sosis ikan pati sagu komposit 50:50 menggunakan alat penetrometer disajikan pada Tabel 1. Rerata tekstur sosis ikan patin akibat rasio pati sagu komposit, terhadap daging ikan berkisar antara 0,03-0,04 mm/g.det. Elliasson and Gudmundsonn (1996), menyatakan bahwa pati fospat dapat meningkatkan stabilitas dan memperbaiki tekstur. Selanjutnya Moedjiharto (2003), menyatakan bahwa perubahan jumlah daging ikan pada sosis akan mempengaruhi kekenyalan sosis, makin banyak daging yang digunakan makin baik kekenyalan dan tekstur sosis yang dihasilkan. Namun semakin banyak bahan tambahan akan mempengaruhi tekstur sosis bahkan dapat meninggalkan sifat khas yang dimiliki oleh sosis. Diduga, semakin banyak pati sagu komposit dan rasio pati sagu komposit terhadap daging ikan, menghasilkan nilai tekstur yang semakin kecil yang artinya bahwa tekstur akan semakin padat/ keras. Mcwilliams (1997), menyatakan bahwa pati alami cenderung membentuk gel yang lembek bila dibanding dengan pati modifikasi. 
Perlakuan rasio pati sagu komposit terhadap daging ikan $30 \%$ berbeda nyata dengan rasio $10 \%$ dan $20 \%$, makin tinggi rasio pati sagu komposit terhadap daging ikan, maka tekstur sosis ikan patin keras dan akibatnya sosis ikan makin padat dan kokoh. Fardias (1985) melaporkan bahwa penguatan struktur gel yang berkaitan dengan elastisitas produk berhubungan erat dengan daya ikat air oleh pati dan kekentalannya. Hadiwiyoto (1983) menyatakan bahwa tekstur yang baik dari sosis yaitu tekstur yang kompak.

\section{Organoleptik}

Hasil pengamatan 25 panelis untuk rasa, tekstur, warna dan bau sosis ikan, dengan metode tingkat kesukaan skala hedonik 1 - 9 (amat sangat tidak suka - amat sangat suka). Hasil uji organolepti sosis ikan berkisar antara 4,2 - 6,44 (agak tidak suka - agak suka); tekstur antara 2,88 6,88 (tidak suka - suka); warna antara 2,88-6,72 ( tidak suka suka); bau antara 5,12 - 6,00 (netral - agak suka).

Tabel 1. Rerata Tekstur Akibat Pengaruh Rasio Pati Sagu Komposit Terhadap Daging Ikan (Table 1. Average Of Tekstur Effect Of Influence Of Composite Ratio Extract Sago To Flesh Fish)

\begin{tabular}{cc}
\hline Rasio pati satu komposit terhadap daging ikan patin $(\% \mathrm{~b} / \mathrm{b})$ & Tekstur (mm/g.det) \\
\hline 10 & $0,04 \mathrm{~b}$ \\
20 & $0,04 \mathrm{ab}$ \\
30 & $0,03 \mathrm{a}$ \\
\hline BNT 0,05 & 0,004
\end{tabular}

Keterangan: Nilai yang didampingi huruf sama pada kolom yang sama menunjukkan pengaruh perlakuan tidak nyata pada uji BNT $(\alpha 0,05)$

Tabel 2. Total Rangking Uji Organoleptik Terhadap Rasa, Tekstur, Warna, Dan Bau Sosis Ikan Patin (Table 2. Totalize Rangking Organoleptik To Feeling. Tekstur, Colour, And Aroma Sausage Fish Of Patin)

\begin{tabular}{|c|c|c|c|c|c|}
\hline $\begin{array}{l}\text { Pati Sagu } \\
\text { Komposit }\end{array}$ & $\begin{array}{l}\text { Rasio Pati Sagu } \\
\text { Komposit terhadap }\end{array}$ & Rasa & Tekstur & Warna & Bau \\
\hline \multirow{3}{*}{$100: 0$} & 10 & $169,0 \quad(1)$ & $165,0 \quad(3)$ & $177,5 \quad(3)$ & $131,5 \quad(4)$ \\
\hline & 20 & 108,0 & $116,5 \quad(6)$ & 113,0 & 112,5 \\
\hline & 30 & 73,0 & $58,0 \quad$ (8) & $49,5 \quad(9)$ & $93,5 \quad$ (9) \\
\hline \multirow{3}{*}{$50: 50$} & 10 & 165,0 & 195,5 & 188,0 & 145,5 \\
\hline & 20 & 117,0 & 148,0 & 133,0 & 118,0 \\
\hline & 30 & $94,5 \quad(7)$ & $57,5 \quad(9)$ & $56,5 \quad$ (8) & 120,0 \\
\hline \multirow{3}{*}{$0: 100$} & 10 & 165,5 & $174,0 \quad(2)$ & 184,5 & 153,0 \\
\hline & 20 & 149,0 & 141,0 & 158,0 & 137,5 \\
\hline & 30 & $83,5 \quad(8)$ & $69,5 \quad(7)$ & $65,0 \quad(7)$ & 113,5 \\
\hline
\end{tabular}

Keterangan : Angka yang didalam kurung menunjukkan rangking berdasarkan Uji Friedman 
Hasil uji organoleptik sosis ikan berkisar antara 4,2 - 6,44 (agak tidak suka - agak suka); tekstur antara 2,88- 6,88 (tidak suka - suka); warna antara 2,88-6,72 ( tidak suka - suka); bau antara 5,12 - 6,00 (netral - agak suka). Hasil analisis keragaman untuk pengujian organoleptik dengan statistik non parametrik uji Friedman menunjukkan bahwa perlakuan pati sagu komposit dan rasio pati sagu komposit terhadap daging ikan memberikan pengaruh yang nyata terhadap rasa, tekstur, warna dan bau sosis ikan. Tabel 2 Berdasarkan total rangking uji organoleptik tingkat kesukaan terhadap rasa, tekstur, warna dan bau sosis ikan patin diperoleh pada perlakuan pati komposit $50: 50$ dengan rasio terhadap daging ikan $10 \%$ (panelis suka) yaitu nilai hasil efektifitas tertinggi 0,9787, merupakan perlakuan terbaik (rangking tertinggi), dengan nilai tektur $0,04 \mathrm{~mm} / \mathrm{g}$.det., sedangkan rangking terendah (panelis tidak suka) diperoleh pada rasio terhadap daging ikan 30\% memperoleh total nilai hasil efektifitas 0,1485 dengan nilai tekstur $0,03 \mathrm{~mm} / \mathrm{g}$.det

\section{KESIMPULAN}

Pati sagu modifikasi fosfat dan risio pati sagu komposit terhadap daging ikan, mempengaruhi sifat organoleptik yaitu; rasa, tekstur, warna dan bau sosis ikan yang dihasilkan. Perlakuan terbaik yang paling disukai oleh panelis adalah pati sagu komposit $50: 50$ dengan rasio $10 \%$ terhadap daging ikan, diperoleh nilai indeks efektifitas tertingg yaitu 0,9787 .

\section{DAFTAR PUSTAKA}

Estiati T. 2006. Teknologi dan Aplikasi Polisakarida dalam Pengolahan Pangan. Jilid I. Penerbit Fakultas Teknologi Pertanian. Universitas Brawijaya. Malang.

Elliasson, A.C. and M. Gudmundsonn. 1996. Starch: Physicochemical and Functional Aspect. In Carbohydrates in Food. Marcell Dekker Inc. New York.

Hadiwiyoto S. 1983. Susu, daging, Telur. Dan Hasil Olahannya. Liberty Yogyakarta.
Handayani. S. 1995. Studi Tentang Pemanfaatan Daging Ikan Cucut (Carcharias sp) sebagai Substitusi Dalam Pembuatan Sosis Ikan Tenggiri (Scomberomorus commersoni). Skripsi. PHP. Fakultas Perikanan. Universitas Brawijaya. Malang.

Haryanto, B dan Pangloli. 1992. Potensi dan Pemanfaatan Sagu. Penerbit Kanisius. Yogyakarta.

Haska, N. 2004. Budidaya Sagu di Lahan Gambut. http:www/pikiranrakyat.com/ cetak/0504106 cakrawaal/lainnya03.Htm

Liu, H. Ramsden and Corke. 1999. Physical Properties and Enzimatic Digestibility of Phosphorilated ae, wx, and Normal Maize Starch Prepared at Different $\mathrm{pH}$ Levels. Cereal Chem, 76(6): 938-943

Moedjiharto T.J. 2003. Evaluasi Fisikokimia Sosis Tempe-Dumbo. Jurnal Teknologi dan Industri Pangan, XIV (2).

Rahayu, W.P. 2001. Penuntun Praktikum Penilaian Organoleptik. Jurusan Teknologi Pangan dan Gizi. Fakultas Teknologi Pangan. IPB. Bogor.

Seib, P.A and Wood, K. 1999. Food Grade Starch Resistant to Alpa Amilase and Method of Preparing the Same. Kansas State University Research Foundation. US Patent 5, 855, 946.

Soeparno, 1992. Ilmu dan Teknologi Daging. Gadjah Mada Universitas Press. Yogyakarta.

Susanto T. dan Yuwono S. 2001. Pengujian Fisik Pangan Unesa University Press Surabaya.

Susrini. 2005. Index Efektifitas. Suatu Pemikiran Tentang Alternatif Untuk Memilih Perlakuan Terbaik Pada Penelitian Pangan. Ed.ke-3 Fakultas Peternakan. Universitas Brawijaya. Malang.

Winarni, A.T dan Fronthea S. 2003. Pemanfaatan Hasil Perikanan Sebagai Produk Bernilai Tambah (Value Added) Dalam Upaya Penganekaragaman Pangan. Jurnal, Teknologi dan Industri Pangan, XIV (1) 7481. 
Lampiran. Hasil Uji Organoleptik dengan Metode Indeks Efektivitas

\begin{tabular}{|c|c|c|c|c|c|c|c|c|c|c|c|c|}
\hline \multirow{2}{*}{$\begin{array}{c}\text { Uji } \\
\text { Organo } \\
\text { leptik }\end{array}$} & \multirow{2}{*}{ BV } & \multirow{2}{*}{ BN } & \multicolumn{2}{|c|}{$\mathrm{P}_{1} \mathrm{R}_{1}$} & \multicolumn{2}{|c|}{$\mathrm{P}_{1} \mathrm{R}_{2}$} & \multicolumn{2}{|c|}{$\mathrm{P}_{1} \mathrm{R}_{3}$} & \multicolumn{2}{|c|}{$\mathrm{P}_{2} \mathrm{R}_{1}$} & \multicolumn{2}{|c|}{$\mathrm{P}_{2} \mathrm{R}_{2}$} \\
\hline & & & $\mathrm{Ne}$ & $\mathrm{Nh}$ & $\mathrm{Ne}$ & $\mathrm{Nh}$ & $\mathrm{Ne}$ & $\mathrm{Nh}$ & $\mathrm{Ne}$ & $\mathrm{Nh}$ & $\mathrm{Ne}$ & $\mathrm{Nh}$ \\
\hline Rasa & 1 & 0,3081 & 0,9643 & 0,2971 & 0,4107 & 0,1265 & 0 & 0 & 1 & 0,3081 & 0,4286 & 0,1320 \\
\hline Tekstur & 0,953 & 0,2880 & 0,8000 & 0,2304 & 0,4200 & 0,1210 & 0,0100 & 0,0029 & 1 & 0,2880 & 0,6500 & 0,1872 \\
\hline Warna & 0,805 & 0,2480 & 0,9167 & 0,2273 & 0,5000 & 0,1240 & 0 & 0 & 1 & 0,2480 & 0,5938 & 0,1473 \\
\hline Bau & 0,506 & 0,1559 & 0,5950 & 0,0921 & 0,3182 & 0,0496 & 0 & 0 & 0,8636 & 0,1346 & 0,3636 & 0,0567 \\
\hline Total & 2,264 & & & 0,8469 & & 0,4211 & & 0,0029 & & 0,9787 & & 0,5232 \\
\hline
\end{tabular}

Lanjutan Lampiran Hasil Uji Organoleptik dengan Metode Indeks Efektivitas

\begin{tabular}{|c|c|c|c|c|c|c|c|c|c|c|}
\hline \multirow{2}{*}{$\begin{array}{c}\text { Uji } \\
\text { Organo } \\
\text { leptik }\end{array}$} & \multirow{2}{*}{ BV } & \multirow{2}{*}{$\mathrm{BN}$} & \multicolumn{2}{|c|}{$\mathrm{P}_{2} \mathrm{R}_{3}$} & \multicolumn{2}{|c|}{$\mathrm{P}_{3} \mathrm{R}_{1}$} & \multicolumn{2}{|c|}{$\mathrm{P}_{3} \mathrm{R}_{2}$} & \multicolumn{2}{|c|}{$\mathrm{P}_{3} \mathrm{R}_{3}$} \\
\hline & & & $\mathrm{Ne}$ & $\mathrm{Nh}$ & $\mathrm{Ne}$ & $\mathrm{Nh}$ & $\mathrm{Ne}$ & $\mathrm{Nh}$ & $\mathrm{Ne}$ & $\mathrm{Nh}$ \\
\hline Rasa & 1 & 0,3081 & 0,1786 & 0,0550 & 0,9290 & 0,2861 & 0,7320 & 0,2256 & 0,1429 & 0,0440 \\
\hline Tekstur & 0,953 & 0,2880 & 0 & 0 & 0,9000 & 0,2592 & 0,5900 & 0,1699 & 0,0900 & 0,0259 \\
\hline Warna & 0,805 & 0,2480 & 0,0625 & 0,0155 & 0,9792 & 0,2428 & 0,7813 & 0,1938 & 0,1250 & 0,0310 \\
\hline Bau & 0,506 & 0,1559 & 0,5000 & 0,0780 & 1 & 0,1559 & 0,6818 & 0,1063 & 0,3636 & 0,0567 \\
\hline Total & 2,264 & & & 0,1485 & & 0,9440 & & 0,6956 & & 0,1576 \\
\hline
\end{tabular}

Keterangan :

$\mathrm{P}_{1} \quad=$ Pati Sagu Komposit $(\mathrm{PSA}+\mathrm{PSMF})=100+0$

$\mathrm{P}_{2} \quad=$ Pati Sagu Komposit $(\mathrm{PSA}+\mathrm{PSMF})=50+50$

$\mathrm{P}_{3} \quad=$ Pati Sagu Komposit $(\mathrm{PSA}+\mathrm{PSMF})=0+100$

$\mathrm{R}_{1}=$ Rasio Pati Sagu Komposit Terhadap Daging Ikan $10 \%$

$\mathrm{R}_{2}=$ Rasio Pati Sagu Komposit Terhadap Daging Ikan $20 \%$

$\mathrm{R}_{3}=$ Rasio Pati Sagu Komposit Terhadap Daging Ikan $30 \%$ 